OPEN ACCESS

Edited by:

Nikos Karamanos,

University of Patras, Greece

Reviewed by:

Pranshu Sahgal,

Dana-Farber Cancer Institute,

United States

Nikolaos A. Afratis,

Weizmann Institute of Science, Israe

${ }^{*}$ Correspondence:

Dali Zheng

dalizheng@fjmu.edu.cn

Bohua Su

sudoctor2005@126.com

${ }^{\dagger}$ These authors have contributed equally to this work

Specialty section:

This article was submitted to Molecular and Cellular Oncology,

a section of the journal

Frontiers in Oncology

Received: 10 November 2021

Accepted: 17 January 2022

Published: 11 February 2022

Citation:

Li Q, Lan T, Xie J, Lu Y,

Zheng D and Su B (2022)

Integrin-Mediated Tumorigenesis and Its Therapeutic Applications.

Front. Oncol. 12:812480. doi: 10.3389/fonc.2022.812480

\section{Integrin-Mediated Tumorigenesis and Its Therapeutic Applications}

\author{
Qingling $\mathrm{Li}^{1,2 \dagger}$, Ting Lan ${ }^{1 \dagger}$, Jian Xie ${ }^{1,2}$, Youguang $\mathrm{Lu}^{1,2}$, Dali Zheng ${ }^{1 *}$ and Bohua Su ${ }^{1,2 *}$ \\ ${ }^{1}$ Fujian Key Laboratory of Oral Diseases, Fujian Provincial Engineering Research Center of Oral Biomaterial, School and \\ Hospital of Stomatology, Fujian Medical University, Fuzhou, China, ${ }^{2}$ Department of Preventive Dentistry, School and Hospital \\ of Stomatology, Fujian Medical University, Fuzhou, China
}

Integrins, a family of adhesion molecules generally exist on the cell surface, are essential for regulating cell growth and its function. As a bi-directional signaling molecule, they mediate cell-cell and cell-extracellular matrix interaction. The recognitions of their key roles in many human pathologies, including autoimmunity, thrombosis and neoplasia, have revealed their great potential as a therapeutic target. This paper focuses on the activation of integrins, the role of integrins in tumorigenesis and progression, and advances of integrin-dependent tumor therapeutics in recent years. It is expected that understanding function and signaling transmission will fully exploit potentialities of integrin as a novel target for tumors.

Keywords: integrin, cancer, signaling transduction, talin, FAK

\section{INTRODUCTION}

Integrins are a type I transmembrane protein and the main ligands for cell adhesion. There are altogether $18 \alpha$ and $8 \beta$ subunits known in mammals, generating 24 kinds of heterodimers (1). Each subunit has a large ectodomain, a single transmembrane domain (TMD) and a comparatively short cytoplasmic tail. The transmembrane region is the key link of information transmission and interaction between TMD and cytoplasmic tail, regulating the affinity between integrins and their ligands. Though they vary in size, the classic $\alpha$ subunit is made up of around 1,000 amino acids, compared with 750 for the $\beta$ subunit (2).

As unique adhesion molecules, integrin can signal in both directions across the plasma membrane. Intracellular activators like talins trigger the conformational changes of integrins and recruit multivalent protein complexes ("clusting") that bind directly or indirectly to the integrin cytoplasmic tail (3-5). These combinations represent a complex, highly dynamic system that relates to ligand-binding affinity, which is responsible for regulating various aspects of cellular fate like cell migration and extracellular matrix (ECM) assembly and remodeling (6). Events introduced above are called "inside-out" signaling. Integrins also enable human cells to respond to changes in the extracellular environment through outside-in signaling. Outside information communicates to cells via intracellular means, bringing about changes in cell polarity, cytoskeletal structure, gene expression, cell survival and proliferation (7).

Integrin heterodimers are often classified by the special sequences they can recognize. Those sequences are generally known as RGD or LDV tripeptides, or some complex peptide like GFOGER. Researchers conventionally classified integrins into 4 types: RGD receptors, collagen receptors, laminin receptors and leukocyte-specific receptors (8). For example, Integrin $\alpha v \beta 3$ binds to a 
spectrum of ECM molecules using the RGD triple-peptide motif (9), which includes von Willebrand factor, fibronectin, fibrinogen, proteolyzed forms of collagen and laminin, and vitronectin. Other integrins, like $\alpha 5 \beta 1$, can only selectively bind to fibronectin (10).

The binding of integrins and ligands are not only located in the classical extracellular matrix (ECM). Integrin interacts with various proteins on the surfaces of cells, even on fungal cells and viruses. Those proteins include hormones, growth factors, and polyphenols (11). Notably, many growth factors bind to the ECM, and the spatial arrangement of integrin and growth factor binding sites in the ECM enables simultaneous engagement of their cognate receptors on the plasma membrane (12). Integrin involves in proliferative signaling, tumor invasion and metastasis, evasion of apoptosis, and stimulation of angiogenesis. This was achieved by cooperating with growth factor receptors like epidermal growth factor receptor (EGFR), ErbB-2 to amplify downstream pathways such as PI3K, AKT, MAPK and the Rho family small GTPases (13). Tejeshwar et al. found that EGFR regulates integrin tension and the spatial organization of focal adhesions, and that the mechanical tension threshold for outside-in integrin activation is tunable by EGFR (14). There are also plenty of non-ECM molecules that interact with integrins, making integrins essential mediators of cell biology.

\section{ACTIVATION AND SIGNAL TRANSMISSION OF INTEGRIN}

Each integrin exists either in the "bent" state of low-affinity or in an extended high-affinity conformation (15-17). The transition from a "bent" to an extended conformation is called "activation," which is reversible and rapid. This process involves two key mechanisms: the extension of the head and the separation of the legs, which are triggered by "inside-out" or "outside-in" signals $(18,19)$. However, recent work clearly illustrated that integrins are vertically positioned on the cell membrane and exist in three main conformations: bent-closed (inactive), extended-closed (active, low affinity) and extended-open (active, high affinity) conformations (20). (Figure 1) There are two common models for activation of integrins: the "switchblade" and the "deadbolt" models, which describe a transition state from the curved one to the extended conformation (21-23). (Figure 2)

As we know, one of the fully studied integrin pathways is the focal adhesion kinase (FAK) signaling pathway. Upon binding to its specific ligand, it leads to maximal FAK activation. The FAKSrc complex has multiple downstream effectors (24). FAK-Src complex promotes the activity of a GTPase which belongs to the Ras superfamily, which is generally known as Racl (Ras-related C3 botulinum toxin substrate 1). Rac1 activation is involved in spreading and in the early stages of migration (25). At later stages of cell spreading or for instance, by constitutive activation of $\alpha v \beta 3$ via ligand binding, RhoA activity leads to the formation of stressfibers and promotes migration (26). In addition, phosphorylation of FAK leads to the Ras-mediated activation of the MAP-kinase pathway (MAPK/ERK pathway), which is associated with proliferation and tumorigenic behavior. Through this pathway, several transcription factors such as the oncogene $\mathrm{C}$-myc and C-jun are activated via phosphorylation. Therefore, the activation of the MAPK pathway leads to the transcription of genes that are important for cell proliferation and cell cycle progression. This pathway can be activated by cell adhesion (e.g., binding of $\alpha 5 \beta 1$ to fibronectin) or growth factors (such as epidermal growth factor (EGF) $(27,28)$. Moreover, phosphorylated FAK connects with PI3K, which leads to the activation of AKT via PDK1 (29). The AKT signaling pathway can also lead to the phosphorylation of YAP which acts as an apoptotic suppressor (30). The activation of YAP represents a cross-talk with a newer signaling pathway known as Hippo pathway. This pathway controls organ size by regulating cell proliferation and apoptosis (31).

Dynamic remodeling of adhesions is an important mechanism employed by cells to regulate integrin-ECM interactions and cellular signaling. This is done through rapid endocytic and exocytic trafficking of integrin receptors during cell migration, invasion and cytokinesis. Integrin traffic is relevant in several pathological processes, especially in cancer. Importantly, conceptual progress in the field has identified well-known cancer oncogenes and mutations as being crucial regulators of integrin traffic. To support their proliferation rate, cancer cells exploit active integrin-mediated ECM endocytosis to directly acquire nutrients from the extracellular environment (32).

Integrin activation is a process of conformational changes which allows integrins to bind their ligands. This process is well modulated through the interaction between the integrin $\alpha / \beta$ cytoplasmic tails (CTs) and their binding partners. Many researchers believe that the change of cytoplasmic tail is the main cause of conformational change (33). Evidence suggests that talins and kindlins are the proteins that bind to cytoplasmic domain and mediate this process (34). In "inside-out" signaling, intracellular activators such as talins or kindlins, binding to the CTs of $\beta$ subunit leads to the separation of the $\alpha$ and $\beta$ tails and induces conformational changes in the ectodomain, thereby increasing its affinity for ligands, also known as the "activation" of integrin $(35,36)$. Conformational changes and clustering of a single integrin can affect affinity to its ligands (15). The affinity of integrin can also be regulated by ligand in vitro to induce conformational changes in the extracellular domain of integrin. Studies suggest that intracellular tensile forces can also lead to integrin activation that is ultrasensitive to lower levels of forces compared with cytoskeletal adaptor binding alone (37). In general, the bi-directional signaling reactions are regulated by the dynamic interaction of integrins and proteins on both sides of the membrane.

Talin is one of the most well-known integrin activators that mediates integrin adherence to the extracellular matrix. Talins activate integrins by binding to the CTs of $\beta$-integrin via its typical 4.1-protein/ezrin/radixin/moesin (FERM) domain. The membrane-proximal NPxY of $\beta$-tail has been identified as the talin-binding site, and the membrane-distal NPxY specifically interacts with kindlins. By binding integrins to actin, talin increases the affinity to the corresponding ligands (integrin activation) as well as recruits a large number of proteins to form the core of the integrin adhesion complex, which in turn activates 


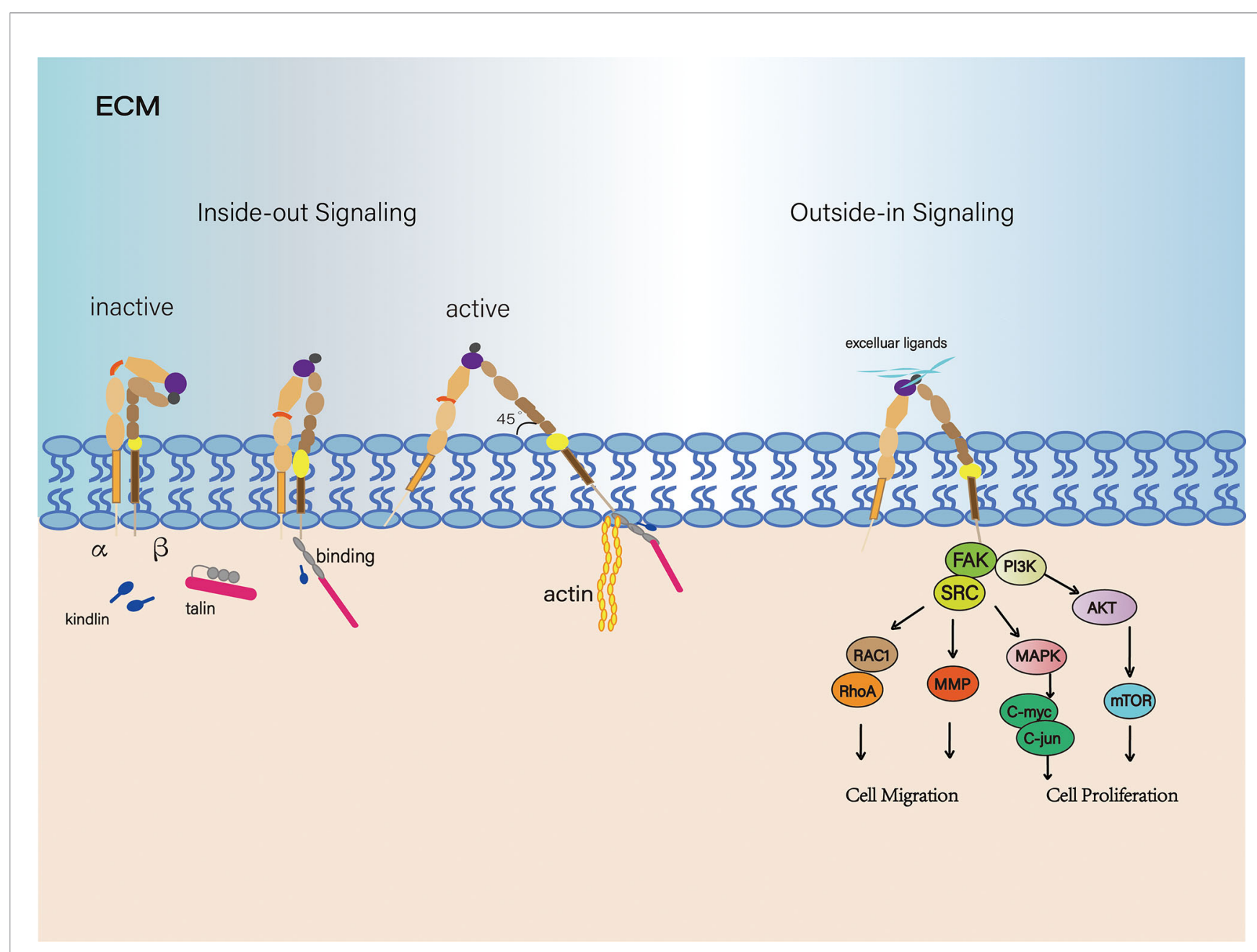

FIGURE 1 | Signal transduction of the integrin family. From an inactive conformation to a low affinity, intermediate state that may arise from talin and/or kindlin binding. And in the active state, integrin subunits were separated, forming a 45 degree angle. Integrins are connected to the actin cytoskeleton and can initiate cytoskeletal remodeling (Left). Integrin-controlled cell migration is largely mediated by signaling pathways involving members of the focal adhesion kinase (FAK)-SRC family kinase. Integrins are ligated and initiate multiple downstream effectors.

adhesion plaque kinases (FAK) and Src family kinases (SFKs) (Figure 1). For example, loss of talin-1 leads to diminished in vivo metastasis of prostate cancer cells via FAK-Src complexes and AKT kinase signaling (38). Downregulation of talin-1 has also been shown to promote hepatocellular carcinoma progression (39). In platelets, talin-1 is the principal direct effector of Rap1 GT Pases that regulates platelet integrin activation in hemostasis (40). Researchers now have established a pipeline approach to evaluate the effect of talin-1 mutations. Through a series of computational methods, biochemical and cell biological analysis, results suggested cancerrelated point mutations in talin-1 can affect cell behaviour and so may contribute to cancer progression (41).

Another family of FERM-containing proteins is kindlins, which are a recently discovered integrin interaction partners that play a synergistic role in talin activation of integrin. Although the molecular details of talin-mediated integrin activation are known, the mechanism of kindlin involvement in this process remains elusive. In the knockout and overexpression experiments, kindlin-1, kindlin-2, and kindlin-3 could regulate specific integrin activation, but only in accordance with the interaction between talin-1 and the cytoplasmic tail of integrin. Activation of integrin $\alpha \operatorname{IIb} \beta 3$ was enhanced by co-expression of kindlin-1 or kindlin- 2 and decreased by knocking out endogenous Si-RNA of kindlin-2. The ligand binding to integrin $\alpha \operatorname{IIb} \beta 3$ is activated due to an overexpressed N-terminal head domain of talin (42-44). Ussar S, et al. found that deletion of kindlin-1 in intestinal epithelial cells or colon cancer cell lines reduced talin-dependent integrin $\beta 1$ activation or directly reduced integrin-mediated cell adhesion (45). Interrupting kindlins' dimer formation impairs kindlinmediated integrin activation (46). Zainab H. used all-atomic microsecond-scale molecular dynamics simulations of integrin aIIb $\beta 3 \mathrm{TM} / \mathrm{CT}$ structure in an explicit lipid-water environment and then found that kindlin-2 cooperates with talin-1 to facilitate integrin aIIb $\beta 3$ activation by enhancing talin- 1 interaction with the membrane proximal (MP) region of $\beta 3$-integrin (47). Both talins and kindlins are essential for integrin conformational 


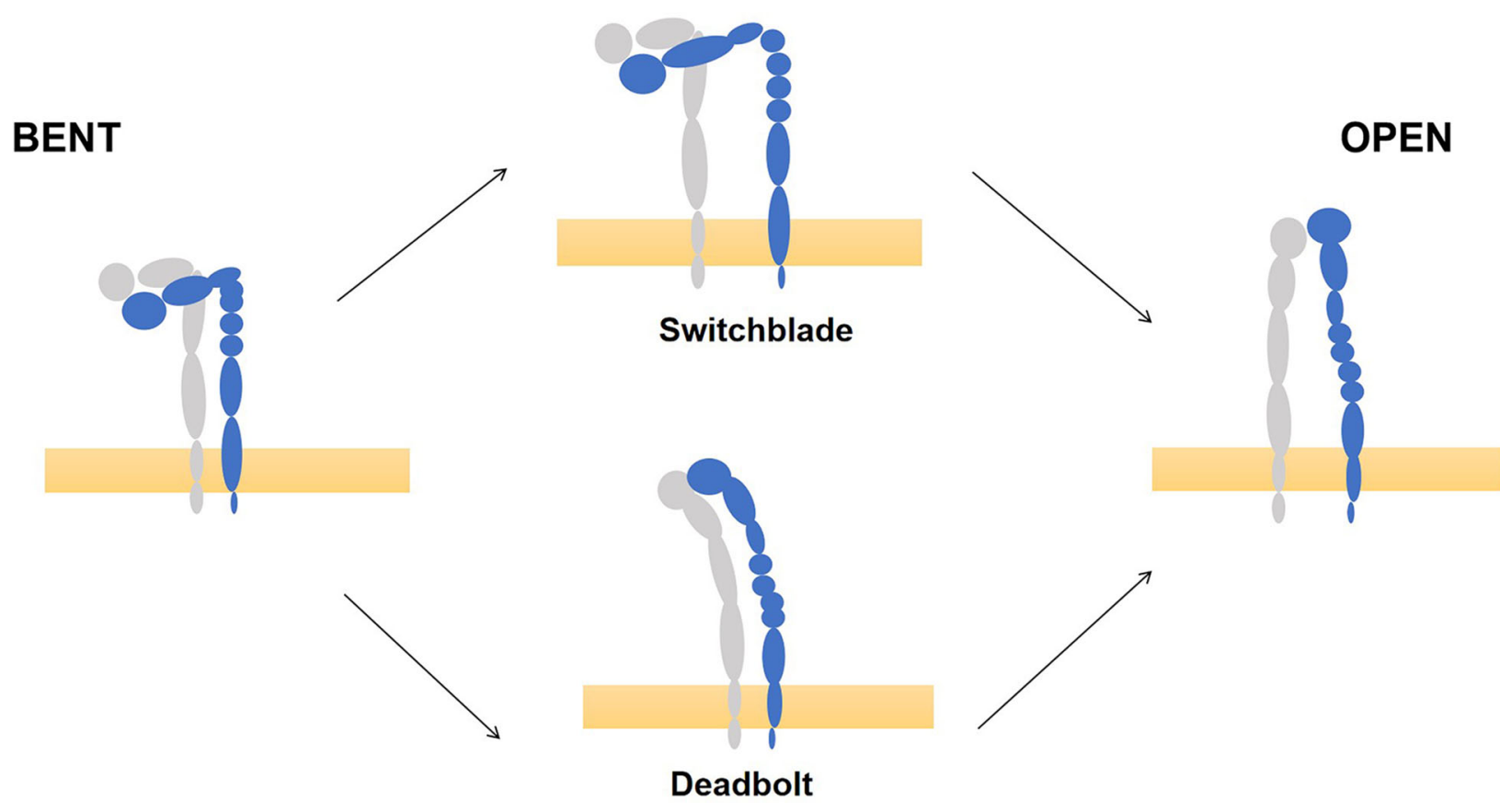

FIGURE 2 | Models of integrin conformational activation. Take integrin $\alpha$ V 33 for example, there are two common models for activation of integrins, the "switchblade" and the "deadbolt" models, to describe a transition state from the low affinity state (left) and high affinity state (right). (This picture modified from Bidone TC. Coarse-Grained Simulation of Full-Length Integrin Activation. Biophys J. 2019 Mar 19;116 (6):1000-1010. doi: 10.1016/j.bpj.2019.02.011. Epub 2019 Feb 22.).

activation, to which they seem to contribute differently by allowing the vinculin-mediated perception of mechanical forces (talins) and triggering biochemical signaling pathways (kindlins) (48), e.g. through paxillin and focal adhesion kinase (FAK) (49-51). Though they cooperatively support integrin activation, the functional significance of post-translational modifications of kindlins controlling integrin signaling has been gradually recognized (52).

When it comes to integrin activation, some accelerants such as paxillin (51, 53), ADAP (54) and migfillin (55) must be mentioned. There are also some inhibitors, such as ICAP-1 $(56)$, filamin $(57,58)$ and sharpin (59), allowing for forfine-tuning of the integrin activation process. Findings showed that sharpin may complex with both kindlin- 1 and the integrin- $\beta 1$ cytoplasmic tail to restrict the talin head domain binding, thus inhibiting $\beta 1$-integrin activation. Besides, integrins also interact with many cytoplasmic proteins, such as Filamina, Dok1 and 14-3-3 proteins, etc. (60).

\section{EFFECTS OF INTEGRINS ON SELF-RENEWAL AND PROLIFERATION OF TUMOR STEM CELLS}

In cancer, the strict control of proliferation is lost due to extrinsic factors such as the presence of mitogenic compounds (growth factors, cytokines or exogenous substances) or intrinsic factors such as activation of oncogenes, converting cancer cells in a selfsufficient entity. In this context, integrins play a crucial role by directly promoting proliferation or by indirectly interacting with growth factor receptors. Interactions between growth factor receptors and integrins in cancer are involved in proliferation. Three types of interactions can be distinguished (1): direct interaction (2), modulation of expression levels and (3) reciprocal activation (61). Integrin signaling has been shown to drive many stem cell functions. Plaks et al. found that specialized extracellular matrix niches and integrin signaling support the function of normal stem cells and their tumor derivatives (62). It has been found that integrin $\beta 1$ mediates the adhesion of basal keratinocytes to the basement membrane in epithelium and controls the stem cell renewal by regulating the polarity axis of asymmetric cell and cell cycle progression (63). The highly expressed laminin binding to integrin $\alpha 6 \beta 1$ of tumor stem cells not only promotes adhesion to the surface of the endothelial basement membrane near the lumen, but also transmits self-renewal signals through FAK (64). Integrin $\alpha \mathrm{V} \beta 5$ could play as a functional cancer stem cell marker essential for glioblastoma maintenance and ZIKV infection, providing potential brain tumor therapy (65). A recent study found arsenic and $\mathrm{BaP}$ co-exposure human bronchial epithelial cells have a high expression of integrin $\alpha 4$, leading to activation of the Hedgehog pathway and PI3K/Akt pathway, enhancing arsenic and $\mathrm{BaP}$ coexposure-induced cancer stem cell (CSC)-like property and tumorigenesis (66). 


\section{ROLE OF INTEGRINS IN ADHESION AND TUMOR INVASION}

Extensive evidence shows that the expression of integrin is significantly different in tumor cells compared to normal ones. Integrin signaling in cancer cells is dysfunctional, which is of significance to understand how tumor cells use integrin activity to regulate invasion and movement and to study the regulatory mechanism of integrin function.

It is well known that the transition from carcinoma in situ to invasive cancer is driven by a series of adhesion changes. By remodeling or dissolving E-cadherin-dependent junctions and integrin-mediated adhesion, unparted cancer cells or groups of cancer cells would separate from adjacent normal cells and the basement membrane below. Through FAK and SFKs, integrins directly phosphorylate E-cadherin- $\beta$-catenin complex to remodeling E-cadherin-dependent junctions, promoting the migration and invasion of cancer cells (67). Integrin-mediated adhesion of fibronectin triggers a negative feedback signal that blocks the formation of E-cadherin mediated cell-to-cell adhesion (68). Putting integrin $\beta 1$ into $\beta 1$-deficient epithelial cells resulted in loss of cell contact and dispersion of cells (69), suggesting that integrin-extracellular matrix adhesion plays an inhibitory role in the regulation of cell-cell junctions. Therefore, the internal and external signals of integrins can disrupt intercellular adhesion by increasing myosins' contractibility and E-cadherin junction stability through FAK and SRC signals (70). Integrin and integrin-dependent processes are implicated in almost every step of cancer development, including tumor growth, invasion and perfusion into the vascular system, survival of circulating tumor cells, extravasation into secondary sites, and metastasis and colonization of new tissues. Integrins expressed on the cell surface is to adhere to the ECM. Ligation provides traction that is essential tumor cell survival and invasion. A recent study has indicated that hypoxia selectively enhances the expression of integrin $\alpha 5 \beta 1$ receptor in breast cancer to promote metastasis (71). The expression and potential roles of thrombospondins (TSP-4) in the crosstalk between CAFs and gallbladder cancer (GBC) cells has remained unclear. Research showed that a complex TSP-4/integrin $\alpha 2 /$ HSF $1 /$ TGF- $\beta$ cascade mediates reciprocal interactions between GBC cells and CAFs, providing a promising therapeutic target for gallbladder cancer patients (72).

For most solid tumors, the basement membrane first needs to be breached. This process is thought to require proteolysis, and integrins play their roles by upregulating the expression of matrix metalloproteinases (MMP) and promoting the activation and function of proteinases at the extracellular matrix. Integrins control cell migration and invasion by influencing the activity and localization of matrix-degrading proteases, such as urokinase-type plasminogen activator (uPA) and MMP2 $(73,74)$ Invasive cancers penetrate the stroma through a variety of different integrin-dependent mechanisms and migrate to surrounding tissues in the form of a single cell or groups of cells (75). Futhermore, tumor-associated fibroblasts
(CAFs) can promote cancer progression through several integrin-related mechanisms. Invasion is caused by deposition or regulation of fiberectin arrangement or by direct physical pulling of cancer cells from the primary tumor (76-79). In order to metastasize smoothly, tumor cells must attach to vasculature in distant organs and penetrate into perivascular tissues. Thrombosis is thought to support cancer metastasis through the recruitment of fibronectin to activate integrins. After extravasation, the contact of integrin with the extracellular matrix in perivascular tissue could determine whether the inoculated tumor cell would continue to proliferate or become dormant state (80-82). Integrin trafficking is also crucial for collective cell migration or morphogenetic movements of cell sheets. Rab-coupling protein (RCP)-dependent integrin recycling pathway was employed by invasive cancer cells for effective migration $(83,84)$.

\section{EFFECTS OF MULTIPLE INTEGRIN SIGNALS ON TUMOR MICROENVIRONMENT}

Generally, tissue has a strictly regulated, specific optimum hardness (85), which is perceived by cells through integrins and their cytoskeletons. Hence, integrins are important mechanical receptors, and together with other adherent proteins such as integrin-activated proteins, talin, nucin and CRK-related substrates, convert mechanical signals into biochemical signals $(86,87)$. Several studies have discussed the role of integrin in angiogenesis, especially the integrin $\alpha \mathrm{v}$. Evidence suggests that integrin $\alpha$ v promotes tumor angiogenesis, depending on environments (88). Integrin $\alpha 6 \beta 4$ may also exert a similar environment-dependent pro-angiogenesis effect (89). In contrast, integrin $\alpha 3 \beta 1$ signaling in endothelial cells negatively regulates tumor angiogenesis by decreasing VEGFR2 expression (90). Signals from integrins also influence other behaviors in the tumor microenvironment. Studies show that TNF $\alpha$ proapoptotic signaling is regulated by the ECM and the integrin that is engaged, and Integrin $\alpha 6 \beta 1$ is inhibitory for the proapoptotic signal of TNF (91).

Integrins play bidirectional regulatory roles between cancer cells and cancer-associated fibroblasts (CAFs). CAFs that express IL-32 contain an RGD cell attachment sequence that binds to integrin $\beta 3$-positive cancer cells to promote breast cancer cell invasion and metastasis (92). CAF-derived extracellular vesicles that express annexin A6 plays a pivotal role in gastric cancer drug resistance via activation of $\beta 1$ integrin-FAK-YAP signaling (93). Colorectal cancer cells express integrin av $\beta 6$ activated CAFs through TGF- $\beta$, which subsequently secrete stromal cellderived factor-1 (SDF-1) and promote colorectal cancer cell metastasis (94). These research studies reveal that integrins act as receptors that regulate the interactions between CAFs and cancer cells in tumor progression and drug resistance. Studies in the future may reveal more about the integrin signaling mechanisms involved about remodeling the tumor 
microenvironment during tumor development. Factors secreted by cancer cells profoundly alter the biology and composition of the stroma by inducing immune cells, triggering angiogenesis, and inducing the activation of CAFs, which generates a lot of tumor-promoting signals (76).

\section{CLINICAL APPLICATION OF INTEGRIN}

Integrins have been seen as potential therapeutic targets since they were discovered to promote pathogenic processes. The inhibition of integrins has led to several marketed drugs, and many others are being investigated preclinically in both academic and industry settings. Since 2015, there have been at least 130 clinical trials of integrin-targeted therapies (95). Unfortunately, there are still a few unsuccessful inhibitors (Table 1). Efalizumab, which targeted $\alpha \mathrm{L}$ integrins, was withdrawn from the market because of multiple cases of progressive multifocal leukoencephalopathy (PML), said to be involved with inhibition of $\alpha 4$-containing integrins and $\alpha \mathrm{L} \beta 2$ (96).

Previous studies have found that $\alpha 4$ and $\beta 2$ integrins are receptors mediating the neutrophil adhesion to the endothelium. Researchers evaluated the $\alpha 4$ and $\beta 2$ integrins' expression and functions in human primary neutrophils obtained from patients having chronic non-healing wounds and undergoing a prolonged hyperbaric oxygen therapy (150 kPa per 90 minutes). Cell adhesion function of both neutrophilic integrins $\alpha 4 \beta 1$ and $\beta 2$ was significantly reduced, which could be of great importance for the design of novel therapeutic protocols focused on antiinflammatory agents (97). Integrin $\alpha \mathrm{V} \beta 3$ is highly expressed on activated endothelial cells of tumor neovasculature and thus is key to tumor angiogenesis. RGD-binding integrins, mainly the $\alpha \mathrm{V}$ integrin subfamily and important to the whole integrin family, are introduced about their expression in different human cancers and their pre-clinical antagonists. (Table 2) New molecules that target $\alpha \mathrm{v}$-containing integrins are now entering clinical trials for fibrotic diseases, including idiopathic pulmonary fibrosis (IPF) and nonalcoholic steatohepatitis (NASH), which have high and increasingly unmet medical need $(95,98,99)$.

Integrins can also be used in diagnostic imaging. Integrininhibiting peptide Apticitide (TC-99M-P280), a gpIIbIIIa imaging technique for the diagnosis of acute deep venious thrombosis, is now available. [99mTc]3PRGD2 imaging is valuable for the diagnosis and staging of esophageal cancer. It may be less sensitive than [18F]FDG imaging for detecting metastatic lesions in small lymph nodes. The T/B value was correlated with the expression of integrin $\alpha \mathrm{V} \beta 3$ (100). Integrin $\alpha \mathrm{V} \beta 3$ in imaging is in the $\mathrm{PH} 2$ trial phase. It is reported that other imaging agents are in the early stage of development (101, 102). As a PET tracer $18 \mathrm{~F}$-Alfatide II has been recently proven to possess good diagnostic value in distinguishing between breast cancer and benign breast lesions (103). Neil et. al found that Ga68 -Trivehexin is a promising probe for imaging of $\alpha \mathrm{V} \beta 6$ integrin expression in human cancers because of its high expression density at the boundary of tumor and healthy tissue (104). Recent studies also show that it may be possible to develop next-generation nanomedicine based on the combined derivatives of resveratrol and tetrac targeting the Integrin $\alpha v \beta 3$ (105).

\section{CONCLUSION}

Integrins have attracted much attention in recent years and are closely related to the development of cancers. We discussed much about the significance of integrin in cell migration and cell adhesion, which are important processes in tumor growth. Integrin-mediated cancer signals are also initiated by several integrin-binding proteins, which include talins, kindlins, MMPs, osteopontin, actinin and so on. Integrins interact with the actin cytoskeleton through these signaling molecules. And because of the polymerization and contraction generated by actin, the main signaling occurs while integrin activates. However, when integrin is misregulated, various mechanisms unfreeze the regulation of integrin signaling in cancer, enabling tumor cells to proliferate unrestrictedly and invade some tissue boundaries, allowing them to survive in microenvironments. The diversity of integrin and their roles in many diseases indicate the great potential of this superfamily as a drug target. Nowadays, designing drugs specific to integrin activation is possible as the structure of integrin has been recognized. By studying the mechanism of integrin and its related signaling pathways, we consider by regulating the expression of integrin or blocking the downstream signaling

TABLE 1 | Integrin-targeting drugs once came out.

\begin{tabular}{|c|c|c|c|c|}
\hline Inhibitor Name & Target & Mechanism & Application & In Market \\
\hline Lifitegrast & $\alpha\llcorner\beta 2$ & $\begin{array}{l}\text { prevents } \\
\text { lymphocyte adhesion }\end{array}$ & Dry eye disease & 2016 \\
\hline Vedolizumab & $\alpha 4 \beta 7$ & $\begin{array}{l}\text { inhibits binding } \\
\text { to MADCAM1 }\end{array}$ & $\begin{array}{l}\text { Ulcerative colitis } \\
\text { and Crohn's disease }\end{array}$ & 2014 \\
\hline Natalizumab & Pan- $\alpha 4$ & $\begin{array}{l}\text { inhibits ligand } \\
\text { binding to } \alpha 4 \beta 7 \text { and } \alpha 4 \beta 1\end{array}$ & $\begin{array}{l}\text { Multiple sclerosis } \\
\text { and Crohn's disease }\end{array}$ & 2004 \\
\hline Efalizumab & $\alpha \mathrm{L}$ & $\begin{array}{l}\text { preventing } \\
\text { lymphocyte activation and migration }\end{array}$ & Plaque psoriasis & $\begin{array}{c}2003 \\
\text { (withdrawn } \\
\text { 2009) }\end{array}$ \\
\hline Tirofiban & $\alpha \operatorname{llb} \beta 3$ & inhibits binding to fibrinogen & $\begin{array}{l}\text { Coronary syndrome } \\
\text { and CVD }\end{array}$ & 1998 \\
\hline Eptifibatide & $\alpha$ llb $\beta 3$ & inhibits binding to fibrinogen & $\begin{array}{l}\text { Coronary syndrome } \\
\text { and CVD }\end{array}$ & 1998 \\
\hline
\end{tabular}


TABLE 2 | $\alpha$-integrins expressed in different human cancers and their pre-clinical antagonists.

\begin{tabular}{|c|c|c|c|c|c|}
\hline Integrin & Cancer Type & Main Expression Feature & Drug & Drug Targeted Cancer Type & $\begin{array}{l}\text { Clinical } \\
\text { Trial }\end{array}$ \\
\hline \multirow[t]{7}{*}{$\alpha \vee \beta 3$} & Gastric cancer & Stroma and endothelia $\uparrow$, correlates with survival & $\begin{array}{l}\text { Etaracizumab } \\
\text { (Abegrin) }\end{array}$ & $\begin{array}{l}\text { Colorectal/melanoma/prostate/ } \\
\text { thyroid cancer }\end{array}$ & Phase ॥ \\
\hline & Glioma & Correlates with grade & $\begin{array}{l}\text { Intetumumab } \\
\text { (CNTO 95) }\end{array}$ & $\begin{array}{l}\text { Colorectal/melanoma/prostate/ } \\
\text { thyroid cancer }\end{array}$ & Phase ॥ \\
\hline & $\begin{array}{l}\text { Lung cancer } \\
\text { brain } \\
\text { metastasis }\end{array}$ & $\begin{array}{r}\text { Endothelia } \uparrow \\
\text { tumor cells } \downarrow\end{array}$ & $\begin{array}{l}\text { Abciximab } \\
\text { (c7E3) }\end{array}$ & Melanoma/breast cancer & Pre-clinical \\
\hline & $\begin{array}{l}\text { Non-small cell } \\
\text { lung } \\
\text { cancer }\end{array}$ & $\begin{array}{l}\text { Endothelia } \uparrow \\
\text { tumor cells } \downarrow\end{array}$ & $\begin{array}{l}\text { Vitaxin } \\
\text { (MEDI-532) }\end{array}$ & Melanoma/breast cancer & Phase ॥ \\
\hline & Oral cancer & Intratumoral endothelia $\uparrow$ & Cilengitide & Melanoma/breast cancer & Phase ॥ \\
\hline & $\begin{array}{l}\text { Pancreatic } \\
\text { cancer }\end{array}$ & Involved in lymph node metastasis & $\mathrm{HM}-3$ & Lung/liver/stomach cancer & Phase I \\
\hline & Prostate cancer & Peritumor $\uparrow$ & AP25 & $\begin{array}{l}\text { Melanoma/gastric/hepatic/breast } \\
\text { carcinoma }\end{array}$ & Pre-clinical \\
\hline \multirow[t]{4}{*}{$\alpha \vee \beta 5$} & Gastric cancer & $\begin{array}{l}\text { Tumor cells, stroma and endothelial cells } \uparrow \text { independent prognostic } \\
\text { factor in intestinal-type }\end{array}$ & $\begin{array}{l}\text { Intetumumab } \\
\text { (CNTO 95) }\end{array}$ & Melanoma/Prostate cancer & Phase ॥ \\
\hline & $\begin{array}{l}\text { Lung cancer } \\
\text { brain } \\
\text { metastasis }\end{array}$ & $\begin{array}{l}\text { Endothelia } \uparrow \\
\text { tumor cells } \downarrow\end{array}$ & Cilengitide & Melanoma/breast cancer & Pre-clinical \\
\hline & $\begin{array}{l}\text { Non-small cell } \\
\text { lung } \\
\text { cancer }\end{array}$ & Tumor and stroma cells $\uparrow$ no correlation with survival & & & \\
\hline & Prostate cancer & Tumor and stroma cells $\uparrow$, no correlation with survival & & & \\
\hline \multirow[t]{2}{*}{$\alpha 5 \beta 1$} & Oral cancer & Stroma $\uparrow$ & $\begin{array}{l}\text { Volociximab } \\
\text { (M200) }\end{array}$ & Melanoma/prostate cancer & Phase II \\
\hline & Ovarian cancer & Correlates with survival & ATN-161 & Glioblastoma & Phase II \\
\hline \multirow[t]{3}{*}{$\alpha \vee \beta 6$} & Gastric cancer & Potential prognostic marker in early stage & $\begin{array}{l}\text { Intetumumab } \\
\text { (CNTO 95) }\end{array}$ & Prostate cancer/melanoma & Phase II \\
\hline & $\begin{array}{l}\text { Basal cell } \\
\text { carcinoma }\end{array}$ & Infiltrative subtype $\uparrow$ & & & \\
\hline & $\begin{array}{l}\text { Non-small cell } \\
\text { lung } \\
\text { cancer }\end{array}$ & $\begin{array}{l}\text { Intratumoral } \\
\text { Heterogeneity } \uparrow\end{array}$ & & & \\
\hline
\end{tabular}

$\uparrow$ means up-regulation; $\downarrow$ means down-regulation.

pathways of integrin to make its function. Although integrins have been discovered for more than 100 years, only a few of their inhibitors have been used in clinical applications, and no specific therapeutic inhibitors have been developed for cancer. Therefore, selectively blocking this acquired migration and invasion ability by targeting key metastatic molecules or regulatory proteins like integrin would be an attractive therapeutic strategy.

\section{AUTHOR CONTRIBUTIONS}

QL and TL reviewed the literature and drafted the article. JX, YL, $\mathrm{DZ}$, and BS finalized the paper and provided suggestions to improve it. All authors participated in designing the concept of

\section{REFERENCES}

1. Hynes RO. Integrins: Bidirectional, Allosteric Signaling Machines. Cell (2002) 110(6):673-87. doi: 10.1016/S0092-8674(02)00971-6

2. Campbell ID, Humphries MJ. Integrin Structure, Activation, and Interactions. Cold Spring Harb Perspect Biol (2011) 3(3):a004994. doi: 10.1101/cshperspect.a004994 this manuscript. All authors contributed to the article and approved the submitted version.

\section{ACKNOWLEDGMENTS}

This work was supported by the National Natural Sciences Foundation of China (grant number: 81872186); the Natural Sciences Foundation of Fujian Province (grant numbers 2019J01318 and 2018J01816); the research grant of Fujian Provincial Education Department (grant number: JT180206). We thank Mr. Lixin Zheng (Georgia Institute of Technology) for the language editing for this manuscript.

3. Horton ER, Byron A, Askari JA, Ng DHJ, Millon-Frémillon A, Robertson J, et al. Definition of a Consensus Integrin Adhesome and Its Dynamics During Adhesion Complex Assembly and Disassembly. Nat Cell Biol (2015) 17 (12):1577-87. doi: 10.1038/ncb3257

4. Horton ER, Humphries JD, James J, Jones MC, Askari JA, Humphries MJ. The Integrin Adhesome Network at a Glance. J Cell Sci (2016) 129 (22):4159-63. doi: 10.1242/jcs.192054 
5. Zaidel-Bar R, Itzkovitz S, Ma'ayan A, Iyengar R, Geiger B. Functional Atlas of the Integrin Adhesome. Nat Cell Biol (2007) 9(8):858-67. doi: 10.1038/ ncb0807-858

6. Calderwood DA, Campbell ID, Critchley DR. Talins and Kindlins: Partners in Integrin-Mediated Adhesion. Nat Rev Mol Cell Biol (2013) 14(8):503-17. doi: $10.1038 / \mathrm{nrm} 3624$

7. Shattil SJ, Kim C, Ginsberg MH. The Final Steps of Integrin Activation: The End Game. Nat Rev Mol Cell Biol (2010) 11(4):288-300. doi: 10.1038/ nrm 2871

8. Humphries JD, Byron A, Humphries MJ. Integrin Ligands at a Glance. J Cell Sci (2006) 119(Pt 19):3901-3. doi: 10.1242/jcs.03098

9. Song Y, Guo X, Fu J, He B, Wang X, Dai W, et al. Dual-Targeting Nanovesicles Enhance Specificity to Dynamic Tumor Cells In Vitro and In Vivo via Manipulation of $\alpha \mathrm{v} \beta 3$-Ligand Binding. Acta Pharm Sin B (2020) 10(11):2183-97. doi: 10.1016/j.apsb.2020.07.012

10. Kuonen F, Surbeck I, Sarin KY, Dontenwill M, Rüegg C, Gilliet M, et al. Tgfß, Fibronectin and Integrin $\alpha 5 \beta 1$ Promote Invasion in Basal Cell Carcinoma. J Invest Dermatol (2018) 138(11):2432-42. doi: 10.1016/j.jid.2018.04.029

11. LaFoya B, Munroe JA, Miyamoto A, Detweiler MA, Crow JJ, Gazdik T, et al. Beyond the Matrix: The Many Non-ECM Ligands for Integrins. Int J Mol Sci (2018) 19(2):449. doi: 10.3390/ijms19020449

12. Cooper J, Giancotti FG. Integrin Signaling in Cancer: Mechanotransduction, Stemness, Epithelial Plasticity, and Therapeutic Resistance. Cancer Cell (2019) 35(3):347-67. doi: 10.1016/j.ccell.2019.01.007

13. Stewart RL, O'Connor KL. Clinical Significance of the Integrin $\alpha 6 \beta 4$ in Human Malignancies. Lab Invest (2015) 95(9):976-86. doi: 10.1038/ labinvest.2015.82

14. Rao TC, Ma VP, Blanchard A, Urner TM, Grandhi S, Salaita K, et al. EGFR Activation Attenuates the Mechanical Threshold for Integrin Tension and Focal Adhesion Formation. J Cell Sci (2020) 133(13):jcs238840. doi: 10.1242/ jcs. 238840

15. Carman CV, Springer TA. Integrin Avidity Regulation: Are Changes in Affinity and Conformation Underemphasized? Curr Opin Cell Biol (2003) 15 (5):547-56. doi: 10.1016/j.ceb.2003.08.003

16. Luo BH, Carman CV, Springer TA. Structural Basis of Integrin Regulation and Signaling. Annu Rev Immunol (2007) 25:619-47. doi: 10.1146/ annurev.immunol.25.022106.141618

17. Ye F, Kim C, Ginsberg MH. Reconstruction of Integrin Activation. Blood (2012) 119(1):26-33. doi: 10.1182/blood-2011-04-292128

18. Shimaoka M, Takagi J, Springer TA. Conformational Regulation of Integrin Structure and Function. Annu Rev Biophys Biomol Struct (2002) 31:485-516. doi: 10.1146/annurev.biophys.31.101101.140922

19. Salas A, Shimaoka M, Phan U, Kim M, Springer TA. Transition From Rolling to Firm Adhesion Can Be Mimicked by Extension of Integrin Alphalbeta2 in an Intermediate Affinity State. J Biol Chem (2006) 281 (16):10876-82. doi: 10.1074/jbc.M512472200

20. Michael M, Parsons M. New Perspectives on Integrin-Dependent Adhesions. Curr Opin Cell Biol (2020) 63:31-7. doi: 10.1016/j.ceb.2019.12.008

21. Takagi J, Petre BM, Walz T, Springer TA. Global Conformational Rearrangements in Integrin Extracellular Domains in Outside-In and Inside-Out Signaling. Cell (2002) 110(5):599-11. doi: 10.1016/S0092-8674 (02)00935-2

22. Lefort CT, Hyun YM, Schultz JB, Law FY, Waugh RE, Knauf PA, et al. Outside-In Signal Transmission by Conformational Changes in Integrin Mac-1. J Immunol (2009) 183(10):6460-8. doi: 10.4049/jimmunol.0900983

23. Xiong JP, Stehle T, Goodman SL, Arnaout MA. New Insights Into the Structural Basis of Integrin Activation. Blood (2003) 102(4):1155-9. doi: 10.1182/blood-2003-01-0334

24. Horton ER, Humphries JD, Stutchbury B, Jacquemet G, Ballestrem C, Barry ST, et al. Modulation of FAK and Src Adhesion Signaling Occurs Independently of Adhesion Complex Composition. J Cell Biol (2016) 212 (3):349-64. doi: 10.1083/jcb.201508080

25. Lawson CD, Ridley AJ. Rho GTPase Signaling Complexes in Cell Migration and Invasion. J Cell Biol (2018) 217(2):447-57. doi: 10.1083/jcb.201612069

26. Huveneers S, Danen EH. Adhesion Signaling - Crosstalk Between Integrins, Src and Rho. J Cell Sci (2009) 122(Pt 8):1059-69. doi: 10.1242/jcs.039446

27. Wen S, Hou Y, Fu L, Xi L, Yang D, Zhao M, et al. Cancer-Associated Fibroblast (CAF)-Derived IL32 Promotes Breast Cancer Cell Invasion and
Metastasis via Integrin $\beta 3$-P38 MAPK Signalling. Cancer Lett (2019) 442:320-32. doi: 10.1016/j.canlet.2018.10.015

28. Yee KL, Weaver VM, Hammer DA. Integrin-Mediated Signalling Through the MAP-Kinase Pathway. IET Syst Biol (2008) 2(1):8-15. doi: 10.1049/ietsyb:20060058

29. Sun F, Wang J, Sun Q, Li F, Gao H, Xu L, et al. Interleukin-8 Promotes Integrin $\beta 3$ Upregulation and Cell Invasion Through PI3K/Akt Pathway in Hepatocellular Carcinoma. J Exp Clin Cancer Res (2019) 38(1):449. doi: 10.1186/s13046-019-1455-x

30. Song G, Ouyang G, Bao S. The Activation of Akt/PKB Signaling Pathway and Cell Survival. J Cell Mol Med (2005) 9(1):59-71. doi: 10.1111/j.15824934.2005.tb00337.x

31. Meng Z, Moroishi T, Guan KL. Mechanisms of Hippo Pathway Regulation. Genes Dev (2016) 30(1):1-17. doi: 10.1101/gad.274027.115

32. Mana G, Valdembri D, Serini G. Conformationally Active Integrin Endocytosis and Traffic: Why, Where, When and How? Biochem Soc Trans (2020) 48(1):83-93. doi: 10.1042/BST20190309

33. Morse EM, Brahme NN, Calderwood DA. Integrin Cytoplasmic Tail Interactions. Biochemistry (2014) 53(5):810-20. doi: 10.1021/bi401596q

34. Essex DW. Redox Control of Platelet Function. Antioxid Redox Signal (2009) 11(5):1191-225. doi: 10.1089/ars.2008.2322

35. Wegener KL, Campbell ID. Transmembrane and Cytoplasmic Domains in Integrin Activation and Protein-Protein Interactions (Review). Mol Membr Biol (2008) 25(5):376-87. doi: 10.1080/09687680802269886

36. Ginsberg MH, Partridge A, Shattil SJ. Integrin Regulation. Curr Opin Cell Biol (2005) 17(5):509-16. doi: 10.1016/j.ceb.2005.08.010

37. Li J, Springer TA. Integrin Extension Enables Ultrasensitive Regulation by Cytoskeletal Force. Proc Natl Acad Sci USA (2017) 114(18):4685-90. doi: 10.1073/pnas.1704171114

38. Sakamoto S, McCann RO, Dhir R, Kyprianou N. Talin1 Promotes Tumor Invasion and Metastasis via Focal Adhesion Signaling and Anoikis Resistance. Cancer Res (2010) 70(5):1885-95. doi: 10.1158/0008-5472.CAN-09-2833

39. Chen P, Lei L, Wang J, Zou X, Zhang D, Deng L, et al. Downregulation of Talin 1 Promotes Hepatocellular Carcinoma Progression Through Activation of the ERK1/2 Pathway. Cancer Sci (2017) 108(6):1157-68. doi: $10.1111 /$ cas. 13247

40. Lagarrigue F, Paul DS, Gingras AR, Valadez AJ, Sun H, Lin J, et al. Talin-1 Is the Principal Platelet Rap1 Effector of Integrin Activation. Blood (2020) 136 (10):1180-90. doi: 10.1182/blood.2020005348

41. Azizi L, Cowell AR, Mykuliak VV, Goult BT, Turkki P, Hytönen VP. Cancer Associated Talin Point Mutations Disorganise Cell Adhesion and Migration. Sci Rep (2021) 11(1):347. doi: 10.1038/s41598-020-77911-4

42. Montanez E, Ussar S, Schifferer M, Bösl M, Zent R, Moser M, et al. Kindlin-2 Controls Bidirectional Signaling of Integrins. Genes Dev (2008) 22(10):132530. doi: $10.1101 / \operatorname{gad} .469408$

43. Ma YQ, Qin J, Wu C, Plow EF. Kindlin-2 (Mig-2): A Co-Activator of Beta3 Integrins. J Cell Biol (2008) 181(3):439-46. doi: 10.1083/jcb.200710196

44. Harburger DS, Bouaouina M, Calderwood DA. Kindlin-1 and -2 Directly Bind the C-Terminal Region of Beta Integrin Cytoplasmic Tails and Exert Integrin-Specific Activation Effects. J Biol Chem (2009) 284(17):11485-97. doi: 10.1074/jbc.M809233200

45. Ussar S, Moser M, Widmaier M, Rognoni E, Harrer C, Genzel-Boroviczeny O, et al. Loss of Kindlin-1 Causes Skin Atrophy and Lethal Neonatal Intestinal Epithelial Dysfunction. PloS Genet (2008) 4(12):e1000289. doi: 10.1371/journal.pgen.1000289

46. Li H, Deng Y, Sun K, Yang H, Liu J, Wang M, et al. Structural Basis of Kindlin-Mediated Integrin Recognition and Activation. Proc Natl Acad Sci USA (2017) 114(35):9349-54. doi: 10.1073/pnas.1703064114

47. Haydari Z, Shams H, Jahed Z, Mofrad MRK. Kindlin Assists Talin to Promote Integrin Activation. Biophys J (2020) 118(8):1977-91. doi: 10.1016/ j.bpj.2020.02.023

48. Sun Z, Costell M, Fässler R. Integrin Activation by Talin, Kindlin and Mechanical Forces. Nat Cell Biol (2019) 21(1):25-31. doi: 10.1038/s41556018-0234-9

49. Theodosiou M, Widmaier M, Böttcher RT, Rognoni E, Veelders M, Bharadwaj M, et al. Kindlin-2 Cooperates With Talin to Activate Integrins and Induces Cell Spreading by Directly Binding Paxillin. Elife (2016) 5: e10130. doi: 10.7554/eLife.10130 
50. Klapproth S, Bromberger T, Türk C, Krüger M, Moser M. A Kindlin-3Leupaxin-Paxillin Signaling Pathway Regulates Podosome Stability. J Cell Biol (2019) 218(10):3436-54. doi: 10.1083/jcb.201903109

51. Zhu L, Liu H, Lu F, Yang J, Byzova TV, Qin J. Structural Basis of Paxillin Recruitment by Kindlin-2 in Regulating Cell Adhesion. Structure (2019) 27 (11):1686-1697.e5. doi: 10.1016/j.str.2019.09.006

52. Bialkowska K, Qin J, Plow EF. Phosphorylation of Kindlins and the Control of Integrin Function. Cells (2021) 10(4):825. doi: 10.3390/cells10040825

53. Gao J, Huang M, Lai J, Mao K, Sun P, Cao Z, et al. Kindlin Supports Platelet Integrin $\alpha$ iib $\beta 3$ Activation by Interacting With Paxillin. J Cell Sci (2017) 130 (21):3764-75. doi: $10.1242 /$ jcs.205641

54. Kasirer-Friede A, Kang J, Kahner B, Ye F, Ginsberg MH, Shattil SJ. ADAP Interactions With Talin and Kindlin Promote Platelet Integrin $\alpha$ iib $\beta 3$ Activation and Stable Fibrinogen Binding. Blood (2014) 123(20):3156-65. doi: 10.1182/blood-2013-08-520627

55. Das M, Ithychanda SS, Qin J, Plow EF. Migfilin and Filamin as Regulators of Integrin Activation in Endothelial Cells and Neutrophils. PloS One (2011) 6 (10):e26355. doi: 10.1371/journal.pone.0026355

56. Bouvard D, Aszodi A, Kostka G, Block MR, Albigès-Rizo C, Fässler R. Defective Osteoblast Function in ICAP-1-Deficient Mice. Development (2007) 134(14):2615-25. doi: 10.1242/dev.000877

57. Ithychanda SS, Qin J. Evidence for Multisite Ligand Binding and Stretching of Filamin by Integrin and Migfilin. Biochemistry (2011) 50(20):4229-31. doi: 10.1021/bi2003229

58. Liu J, Das M, Yang J, Ithychanda SS, Yakubenko VP, Plow EF, et al. Structural Mechanism of Integrin Inactivation by Filamin. Nat Struct Mol Biol (2015) 22(5):383-9. doi: 10.1038/nsmb.2999

59. Rantala JK, Pouwels J, Pellinen T, Veltel S, Laasola P, Mattila E, et al. SHARPIN Is an Endogenous Inhibitor of $\beta 1$-Integrin Activation. Nat Cell Biol (2011) 13(11):1315-24. doi: 10.1038/ncb2340

60. Gao J, Bao Y, Ge S, Sun P, Sun J, Liu J, et al. Sharpin Suppresses $\beta 1$-Integrin Activation by Complexing With the $\beta 1$ Tail and Kindlin-1. Cell Commun Signal (2019) 17(1):101. doi: 10.1186/s12964-019-0407-6

61. Bianconi D, Unseld M, Prager GW. Integrins in the Spotlight of Cancer. Int J Mol Sci (2016) 17(12):2037. doi: 10.3390/ijms17122037

62. Plaks V, Kong N, Werb Z. The Cancer Stem Cell Niche: How Essential Is the Niche in Regulating Stemness of Tumor Cells? Cell Stem Cell (2015) 16 (3):225-38. doi: 10.1016/j.stem.2015.02.015

63. Lechler T, Fuchs E. Asymmetric Cell Divisions Promote Stratification and Differentiation of Mammalian Skin. Nature (2005) 437(7056):275-80. doi: 10.1038 /nature 03922

64. Lathia JD, Gallagher J, Heddleston JM, Wang J, Eyler CE, Macswords J, et al. Integrin Alpha 6 Regulates Glioblastoma Stem Cells. Cell Stem Cell (2010) 6 (5):421-32. doi: 10.1016/j.stem.2010.02.018

65. Zhu Z, Mesci P, Bernatchez JA, Gimple RC, Wang X, Schafer ST, et al. Zika Virus Targets Glioblastoma Stem Cells Through a SOX2-Integrin $\alpha v \beta 5$ Axis. Cell Stem Cell (2020) 26(2):187-204.e10. doi: 10.1016/j.stem.2019.11.016

66. Xie J, Yang P, Lin HP, Li Y, Clementino M, Fenske W, et al. Integrin $\alpha 4$ UpRegulation Activates the Hedgehog Pathway to Promote Arsenic and Benzo $[\alpha]$ Pyrene Co-Exposure-Induced Cancer Stem Cell-Like Property and Tumorigenesis. Cancer Lett (2020) 493:143-55. doi: 10.1016/j.canlet. 2020.08.015

67. Murphy DA, Courtneidge SA. The 'Ins' and 'Outs' of Podosomes and Invadopodia: Characteristics, Formation and Function. Nat Rev Mol Cell Biol (2011) 12(7):413-26. doi: 10.1038/nrm3141

68. Borghi N, Lowndes M, Maruthamuthu V, Gardel ML, Nelson WJ. Regulation of Cell Motile Behavior by Crosstalk Between Cadherin- and Integrin-Mediated Adhesions. Proc Natl Acad Sci USA (2010) 107 (30):13324-9. doi: 10.1073/pnas.1002662107

69. Gimond C, van der Flier A, van Delft S, Brakebusch C, Kuikman I, Collard JG, et al. Induction of Cell Scattering by Expression of Betal Integrins in Beta1-Deficient Epithelial Cells Requires Activation of Members of the Rho Family of GTPases and Downregulation of Cadherin and Catenin Function. J Cell Biol (1999) 147(6):1325-40. doi: 10.1083/jcb.147.6.1325

70. Martinez-Rico C, Pincet F, Thiery JP, Dufour S. Integrins Stimulate ECadherin-Mediated Intercellular Adhesion by Regulating Src-Kinase Activation and Actomyosin Contractility. J Cell Sci (2010) 123(Pt 5):71222. doi: $10.1242 /$ jcs. 047878
71. Ju JA, Godet I, Ye IC, Byun J, Jayatilaka H, Lee SJ, et al. Hypoxia Selectively Enhances Integrin $\alpha 5 \beta 1$ Receptor Expression in Breast Cancer to Promote Metastasis. Mol Cancer Res (2017) 15(6):723-34. doi: 10.1158/15417786.MCR-16-0338

72. Shi Y, Sun L, Zhang R, Hu Y, Wu Y, Dong X, et al. Thrombospondin 4/ Integrin $\alpha 2 / H S F 1$ Axis Promotes Proliferation and Cancer Stem-Like Traits of Gallbladder Cancer by Enhancing Reciprocal Crosstalk Between CancerAssociated Fibroblasts and Tumor Cells. J Exp Clin Cancer Res (2021) 40 (1):14. doi: 10.1186/s13046-020-01812-7

73. Hamidi H, Ivaska J. Every Step of the Way: Integrins in Cancer Progression and Metastasis. Nat Rev Cancer (2018) 18(9):533-48. doi: 10.1038/s41568018-0038-Z

74. Yue J, Zhang K, Chen J. Role of Integrins in Regulating Proteases to Mediate Extracellular Matrix Remodeling. Cancer Microenviron (2012) 5(3):275-83. doi: $10.1007 /$ s12307-012-0101-3

75. Munshi HG, Stack MS. Reciprocal Interactions Between Adhesion Receptor Signaling and MMP Regulation. Cancer Metastasis Rev (2006) 25(1):45-56. doi: 10.1007/s10555-006-7888-7

76. Attieh Y, Vignjevic DM. The Hallmarks of CAFs in Cancer Invasion. Eur J Cell Biol (2016) 95(11):493-502. doi: 10.1016/j.ejcb.2016.07.004

77. Attieh Y, Clark AG, Grass C, Richon S, Pocard M, Mariani P, et al. CancerAssociated Fibroblasts Lead Tumor Invasion Through Integrin- $\beta 3$ Dependent Fibronectin Assembly. J Cell Biol (2017) 216(11):3509-20. doi: 10.1083/jcb.201702033

78. Erdogan B, Ao M, White LM, Means AL, Brewer BM, Yang L, et al. CancerAssociated Fibroblasts Promote Directional Cancer Cell Migration by Aligning Fibronectin. J Cell Biol (2017) 216(11):3799-816. doi: 10.1083/ jcb.201704053

79. Labernadie A, Kato T, Brugués A, Serra-Picamal X, Derzsi S, Arwert E, et al. A Mechanically Active Heterotypic E-Cadherin/N-Cadherin Adhesion Enables Fibroblasts to Drive Cancer Cell Invasion. Nat Cell Biol (2017) 19 (3):224-37. doi: 10.1038/ncb3478

80. Knowles LM, Gurski LA, Engel C, Gnarra JR, Maranchie JK, Pilch J. Integrin $\alpha v \beta 3$ and Fibronectin Upregulate Slug in Cancer Cells to Promote Clot Invasion and Metastasis. Cancer Res (2013) 73(20):6175-84. doi: 10.1158/ 0008-5472.CAN-13-0602

81. Malik G, Knowles LM, Dhir R, Xu S, Yang S, Ruoslahti E, et al. Plasma Fibronectin Promotes Lung Metastasis by Contributions to Fibrin Clots and Tumor Cell Invasion. Cancer Res (2010) 70(11):4327-34. doi: 10.1158/00085472.CAN-09-3312

82. Lambert AW, Pattabiraman DR, Weinberg RA. Emerging Biological Principles of Metastasis. Cell (2017) 168(4):670-91. doi: 10.1016/ j.cell.2016.11.037

83. Paul NR, Jacquemet G, Caswell PT. Endocytic Trafficking of Integrins in Cell Migration. Curr Biol (2015) 25(22):R1092-105. doi: 10.1016/ j.cub.2015.09.049

84. Wojnacki J, Galli T. Membrane Traffic During Axon Development. Dev Neurobiol (2016) 76(11):1185-200. doi: 10.1002/dneu.22390

85. Handorf AM, Zhou Y, Halanski MA, Li WJ. Tissue Stiffness Dictates Development, Homeostasis, and Disease Progression. Organogenesis (2015) 11(1):1-15. doi: 10.1080/15476278.2015.1019687

86. Matsui H, Harada I, Sawada Y. Src, p130Cas, and Mechanotransduction in Cancer Cells. Genes Cancer (2012) 3(5-6):394-401. doi: 10.1177/ 1947601912461443

87. Sun Z, Guo SS, Fässler R. Integrin-Mediated Mechanotransduction. J Cell Biol (2016) 215(4):445-56. doi: 10.1083/jcb.201609037

88. Robinson SD, Hodivala-Dilke KM. The Role of $\beta 3$-Integrins in Tumor Angiogenesis: Context Is Everything. Curr Opin Cell Biol (2011) 23(5):6307. doi: 10.1016/j.ceb.2011.03.014

89. Guo W, Pylayeva Y, Pepe A, Yoshioka T, Muller WJ, Inghirami G, et al. Beta 4 Integrin Amplifies ErbB2 Signaling to Promote Mammary Tumorigenesis. Cell (2006) 126(3):489-502. doi: 10.1016/j.cell.2006.05.047

90. da Silva RG, Tavora B, Robinson SD, Reynolds LE, Szekeres C, Lamar J, et al. Endothelial Alpha3beta1-Integrin Represses Pathological Angiogenesis and Sustains Endothelial-VEGF. Am J Pathol (2010) 177(3):1534-48. doi: 10.2353/ajpath.2010.100043

91. Huang P, Rani MR, Ahluwalia MS, Bae E, Prayson RA, Weil RJ, et al. Endothelial Expression of TNF Receptor-1 Generates a Proapoptotic Signal 
Inhibited by Integrin $\alpha 6 \beta 1$ in Glioblastoma. Cancer Res (2012) 72(6):142837. doi: 10.1158/0008-5472.CAN-11-2621

92. Wen S, Hou Y, Fu L, Xi L, Yang D, Zhao M, et al. Cancer-Associated Fibroblast (CAF)-Derived IL32 Promotes Breast Cancer Cell Invasion and Metastasis via Integrin B3-P38 MAPK Signalling. Cancer Lett (2019) 442:320e32. doi: 10.1016/j.canlet.2018.10.015

93. Uchihara T, Miyake K, Yonemura A, Komohara Y, Itoyama R, Koiwa M, et al. Extracellular Vesicles From Cancer-Associated Fibroblasts Containing Annexin A6 Induces FAK-YAP Activation by Stabilizing B1 Integrin, Enhancing Drug Resistance. Cancer Res (2020) 80:3222e35. doi: 10.1158/ 0008-5472.CAN-19-3803

94. Peng C, Zou X, Xia W, Gao H, Li Z, Liu N, et al. Integrin Avb6 Plays a BiDirectional Regulation Role Between Colon Cancer Cells and CancerAssociated Fibroblasts. Biosci Rep (2018) 38:BSR20180243. doi: 10.1042/ BSR20180243

95. Slack RJ, Macdonald SJF, Roper JA, Jenkins RG, Hatley RJD. Emerging Therapeutic Opportunities for Integrin Inhibitors. Nat Rev Drug Discov (2022) 21(1):60-78. doi: 10.1038/s41573-021-00284-4

96. Raab-Westphal S, Marshall JF, Goodman SL. Integrins as Therapeutic Targets: Successes and Cancers. Cancers (Basel) (2017) 9(9):110. doi: $10.3390 /$ cancers 9090110

97. Baiula M, Greco R, Ferrazzano L, Caligiana A, Hoxha K, Bandini D, et al. Integrin-Mediated Adhesive Properties of Neutrophils Are Reduced by Hyperbaric Oxygen Therapy in Patients With Chronic Non-Healing Wound. PloS One (2020) 15(8):e0237746. doi: 10.1371/journal.pone.0237746

98. Xie B, Ren Y, Geng J, He X, Ban C, Wang S, et al. Idiopathic Pulmonary Fibrosis Registry China Study (PORTRAY): Protocol for a Prospective, Multicentre Registry Study. BMJ Open (2020) 10(11):e036809. doi: 10.1136/ bmjopen-2020-036809

99. Abeysekera KWM, Fernandes GS, Hammerton G, Portal AJ, Gordon FH, Heron J, et al. Prevalence of Steatosis and Fibrosis in Young Adults in the UK: A Population-Based Study. Lancet Gastroenterol Hepatol (2020) 5 (3):295-305. doi: 10.1016/S2468-1253(19)30419-4

100. Zheng S, Chen Z, Huang C, Chen Y, Miao W. [99mtc]3PRGD2 for Integrin Receptor Imaging of Esophageal Cancer: A Comparative Study With [18F]
FDG PET/Ct. Ann Nucl Med (2019) 33(2):135-43. doi: 10.1007/s12149-0181315-3

101. Sun CC, Qu XJ, Gao ZH. Arginine-Glycine-Aspartate-Binding Integrins as Therapeutic and Diagnostic Targets. Am J Ther (2016) 23(1):e198-207. doi: 10.1097/MJT.0000000000000053

102. Shi J, Wang F, Liu S. Radiolabeled Cyclic RGD Peptides as Radiotracers for Tumor Imaging. Biophys Rep (2016) 2(1):1-20. doi: 10.1007/s41048-0160021-8

103. Wu J, Wang S, Zhang X, Teng Z, Wang J, Yung BC, et al. 18f-Alfatide II PET/ CT for Identification of Breast Cancer: A Preliminary Clinical Study. J Nucl Med (2018) 59(12):1809-16. doi: 10.2967/jnumed.118.208637

104. Quigley NG, Steiger K, Hoberück S, Czech N, Zierke MA, Kossatz S, et al. PET/CT Imaging of Head-and-Neck and Pancreatic Cancer in Humans by Targeting the "Cancer Integrin" $\alpha v \beta 6$ With Ga-68-Trivehexin. Eur J Nucl Med Mol Imaging (2021) 24:1-12. doi: 10.1007/s00259-021-05559-x

105. Cheng TM, Chang WJ, Chu HY, De Luca R, Pedersen JZ, Incerpi S, et al. Nano-Strategies Targeting the Integrin $\alpha v \beta 3$ Network for Cancer Therapy. Cells (2021) 10(7):1684. doi: 10.3390/cells10071684

Conflict of Interest: The authors declare that the research was conducted in the absence of any commercial or financial relationships that could be construed as a potential conflict of interest.

Publisher's Note: All claims expressed in this article are solely those of the authors and do not necessarily represent those of their affiliated organizations, or those of the publisher, the editors and the reviewers. Any product that may be evaluated in this article, or claim that may be made by its manufacturer, is not guaranteed or endorsed by the publisher.

Copyright $\odot 2022 \mathrm{Li}$, Lan, Xie, Lu, Zheng and Su. This is an open-access article distributed under the terms of the Creative Commons Attribution License (CC BY). The use, distribution or reproduction in other forums is permitted, provided the original author(s) and the copyright owner(s) are credited and that the original publication in this journal is cited, in accordance with accepted academic practice. No use, distribution or reproduction is permitted which does not comply with these terms. 